\title{
Patron-Client Relationship between Village Heads and Their Residents during the Covid-19 Pandemic
}

\author{
${ }^{1}$ DWI WAHYU PRASETYONO, ${ }^{2}$ ENDIK HIDAYAT, \\ ${ }^{3}$ RUSTONO FARADY MARTA, ${ }^{4}$ LAURENCIA STEFFANIE MEGA WIJAYA \\ KURNIAWATI, ${ }^{5}$ MAICHEL CHINMI \\ 1,2 Department of Public Administration, Wijaya Putra University, Surabaya \\ 3,4 Master's Degree of Communication Science Department, Universitas Bunda Mulia, Jakarta \\ ${ }^{5}$ Master's Degree of Communication Science Department, Universitas Bunda Mulia, Banten \\ Correspondence author: rmarta@bundamulia.ac.id
}

\begin{abstract}
This article will understand the role of the village's head during the COVID-19 pandemic in Sampang regency in 2020 . This article utilizes status and role theory by Linton to elaborate role, role facilities, and role-set the village head status as an analytical tool. Then the patron-client theory by Scott is used to understand the village head's position as the "father" of the villagers. This article uses a qualitative approach and takes a case study of ten villages in Sampang Regency, East Java Province. The data collection technique was carried out through in-depth interviews with ten village heads and secondary data from the internet, namely the Sampang local government's official website and local news online media. This article discovers that the role of village heads during a pandemic includes: the role of shaping public opinion to be aware of the COVID-19 virus, the role of consolidation through volunteers and information centers (Call Center), and the role of facilitators in the COVID-19 social assistance program. Besides, this article finds that the patron-client relationship between the village head and residents is still strong enough that the village head as the formal leader as well as the informal leader as the village protector during the pandemic.
\end{abstract}

Keywords: COVID-19 Pandemic, Role, Patron-Client, Public Opinion. Sampang Regency

\section{Introduction}

The outbreak of Coronavirus Disease 2019 (COVID-19) in Indonesia has pushed the alteration towards the society's living order further down to the village level. The village government has implemented rules to minimize disease transmissions, such as prohibiting mass activities, social distancing, and physical distancing. The village government's role and involvement are through encouraging villagers to practice healthy lifestyles, such as using a face mask and frequently washing hands when outside(Chen et al., 2020).

The existence and the role of a village head will be more visible during this COVID-19 pandemic situation. As a formal leader and village's model figure, a village head possess the power authority (Pratt \& Yongvanit,
2016), (Steenbergen, 2016). He/she is able to influence the villagers to observe health protocol in daily activities, which is still based on the concept of "gotong royong" (mutual assistance, sharing burdens between the members of the community). Activities conducted is related to the disease transmission preventions such as disinfection in public facilities, building command center, and maintain neighborhood cleanliness. These kinds of characteristics make the villagers are different from their urban brothers. From the phenomenon that occurred above, Law No. $6 / 2014$ about Village provides a large space for village leadership and its people(Phahlevy \& Multazam, 2018).

A Villager, as a citizen, has a concern towards the governance of the village government and its services. On the other side, the village government is conducted

Received: 2019-09-13, Revised: 2020-01-22, Accepted: 2020-12-16

Print ISSN: 0215-8175; Online ISSN: 2303-2499. DOI: https://doi.org/10.29313/mimbar.v36i2.6845

Accredited Sinta 2 based on the decree No.10/E/KPT/2019 until 2024. Indexed by DOAJ, Sinta, Garuda, Crossreff, Dimensions 
to be in line with the villager's positive perceptions: improving governance and services. Various activities and budgeting that enters villages after the bill is legislated have a great potential to satisfy the villagers (Lisnawati \& Lestari, 2019).

However, Sampang's regent instructs the budgeting for the COVID-19 pandemic in Sampang through the utilization of Village Budget (DD) and Village Budget Allocation (ADD) (Sampang Communication and Information Board, 2020); (Regent of Sampang, 2019). This policy is passed to anticipate Coronavirus spreading through Sampang's regent's Circulation Letter number $440 / 655 / 434.203 / 2020$ about Effort on Prevention of COVID-19 Transmission. This letter explicitly organizes the village head to stock up face mask to later distribute it to the villagers for free. Face mask procurement at the village level must utilize the village's local micro, small, and medium enterprises (Basri, 2020).

The Figure 1 illustrates the statistics of cumulative COVID-19 transmission in Sampang regency by 18 September 2020, which are divided into three categories: confirmed, suspect, and probable.

Based on the figure 1, there have been 247 confirmed cases and five suspected cases of COVID-19. Sampang's government has passed many policies to maintain its green zone status (no active COVID-19 cases), which this policy later followed up by village governments. In the village's social life, the village head's role is a formal elite of community mover in observing health protocols in the era of new life habits adaptation (New Normal). From a formal authority perspective, the village head can use its authority channels to take action against the violation of New Normal policies and strengthen its position as the village head(Salim et al., 2017). Its status as the distributor of villager's welfare programs is evident in giving certain power to make sure which villager has the right to receive social aid.

Related to its position as the intermediary party of the Supradesa government program (Aspinall \& Rohman, 2017) the village head greatly influences its villagers. $\mathrm{He} / \mathrm{she}$ gets more respect from their people, compared to other village elites such as religious leaders, entrepreneurs, etc. This leadership passed the formal political region towards the informal spectrum, which demands the village head to has its initiatives to move the village forward and protect the village from the COVID-19 disease. To ease these initiatives' implementation, the village heads frequently utilize their power networks above: the district and regent/city level bureaucracy.

However, the various roles of village heads in handling the pandemic are interesting as a research object because, by the empirical fact, there has been no research that specifically focused on the village head's roles in the pandemic situation. Furthermore, to ease on seeing the research significance compared to previous studies, the authors will dissect the previous studies as follows: (1) (Hidayat, 2016) who researched the roles of Islamic clerics (kyai) in the political constellation of 2014 Indonesian Presidential Election. The research concludes that there are four roles of the kyai, which are using religion for political purposes, opinion maker, facilitator, and campaigner and mass mover; (2) Research from (Latifah \& Larasati, 2018) discusses the Malang Corruption Watch (MCW) role, a civilian organization, during the 2017 Batu City Regional Election. The role of $\mathrm{MCW}$ is to monitor, investigate,

Figure 1. Sampang regency's COVID-19 situation development

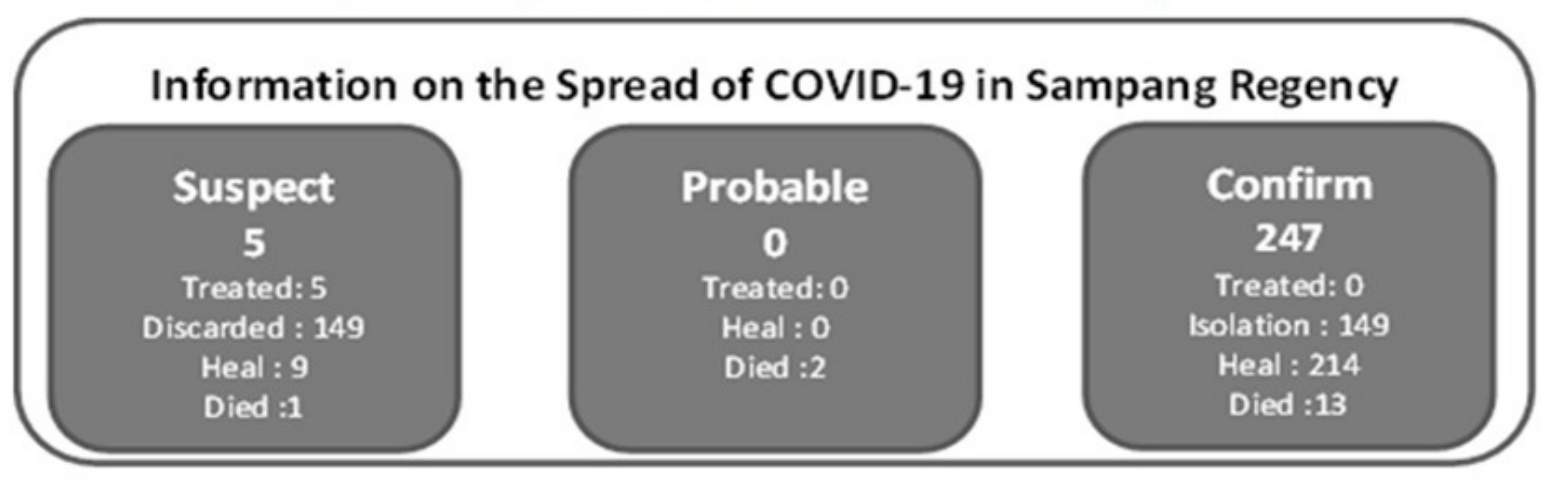

Source: (sampangkab.go.id, 2020) 
advocate, and to discover corruption cases; (3) (Hidayaturrahman, 2020) investigates people's representatives in the Sumenep electoral region.

This study found the two roles of the people's representatives; budgeting and control. The budgeting role focuses on the representative that fights for people's aspirations in grant programs towards society. The control role focuses on the observing government program on society's welfares.

Reviewing previous studies on the role of political actors, then, in the academic context, this research is expected to provide theoretical significance towards role theory in analyzing forms of village head's role in an abnormal situation due to COVID-19 pandemic. In the policy context, this study is expected to contribute a piece of knowledge to the policymakers at the village level: on one side, this pandemic crisis can directly encourage the public officials' initiative to make public service innovation at the village level.

A village head's duty as the protector of the village is not determined by its certain authority level that has to be owned but integrated more in a traditional "measurement" as "protecting father" for the villagers (Thongpoon, 2012); (Musta'an, 2019). Therefore, the village head's fundamental relationship and its followers (villagers) is a patron-client relationship. According to Scott (1972), the patron-client relationship is a special case from the bond between two people that are involved in an instrumental friendship where the higher social-economic status person (patron) uses its wealth and influence to provide protections and benefits towards those in the lower status (client), which is client then return it in the form of support and assistance, including private service, towards their patron (Hidayat \& Miskan, 2018).

The essential factor in the patron-client relationship is the power relation. A patron is a person with the power towards the client because the patron has more abilities than the client, which are influence and living necessity sources. With its advantages, the patron can provide protection and living necessities needed by other people that later agree to be their client. The existence of protection and the giving of living necessities then generates supports and services towards the patron as a return (Nurhadi \& Sunarso, 2018).
Therefore, the village elites' responsibilities during the pandemic, represented by village heads and their apparatus, aim towards the patron's moral duty to keep villagers (or clients) safe. The village elites have a job on realizing welfare programs for the villagers, instructed from the Supradesa bureaucratic structures, which are district head and regent. Formally, the village head can utilize those authority channels to strengthen its position as a village leader. Its role as the distributor of government program's information gives the village head specific power to act in social aid allocation policy for the villagers impacted by the COVID-19 pandemic.

Furthermore, the village head is involved in handling the pandemic situation because of the respected role and status in society. In the sociological approach put forward by Soekanto, the role is a dynamic aspect of status(Soekanto \& Sulistyowati, 2005).

If someone conducted its rights and duties in line with its status, this person would conduct a role. Linton (1964) develops role theory and illustrates social interactions in actors' terminology that suitably match anything determined by the culture(Heckman \& Galletta, 1988). In line with this theory, the expectation of role is a common understanding that guides the behavior in the daily activities (Coser \& Rosenberg, 1964)

An individual can conduct its role in society if he/she has the role of facilities. These facilities are provided by the society for an individual to conduct its role, such as in social institutions. These social institutions are the part of society that provides ample of opportunities for the role implementations (Mei Ling, 2020). Sometimes, the alteration of a social group structure can result in facilities' addition. For example, during this pandemic situation, the village head owns the office or meeting hall, command post for COVID-19 task forces, also holding the management of village enterprises and bureaucracy. Concerning the status and the role of the Sampang's village head during the pandemic can be illustrated by Ralph Linton's role theory concept in figure 2 (Biddle, 1986).

Figure 2 shows that besides own the role facilities, the village head, in conducting its political roles, also has other support (role set). For example, a village head that interacted with particular actors in the political and social communal system such as regent, district head, entrepreneurs, social organizations such as Empowerment of Family 


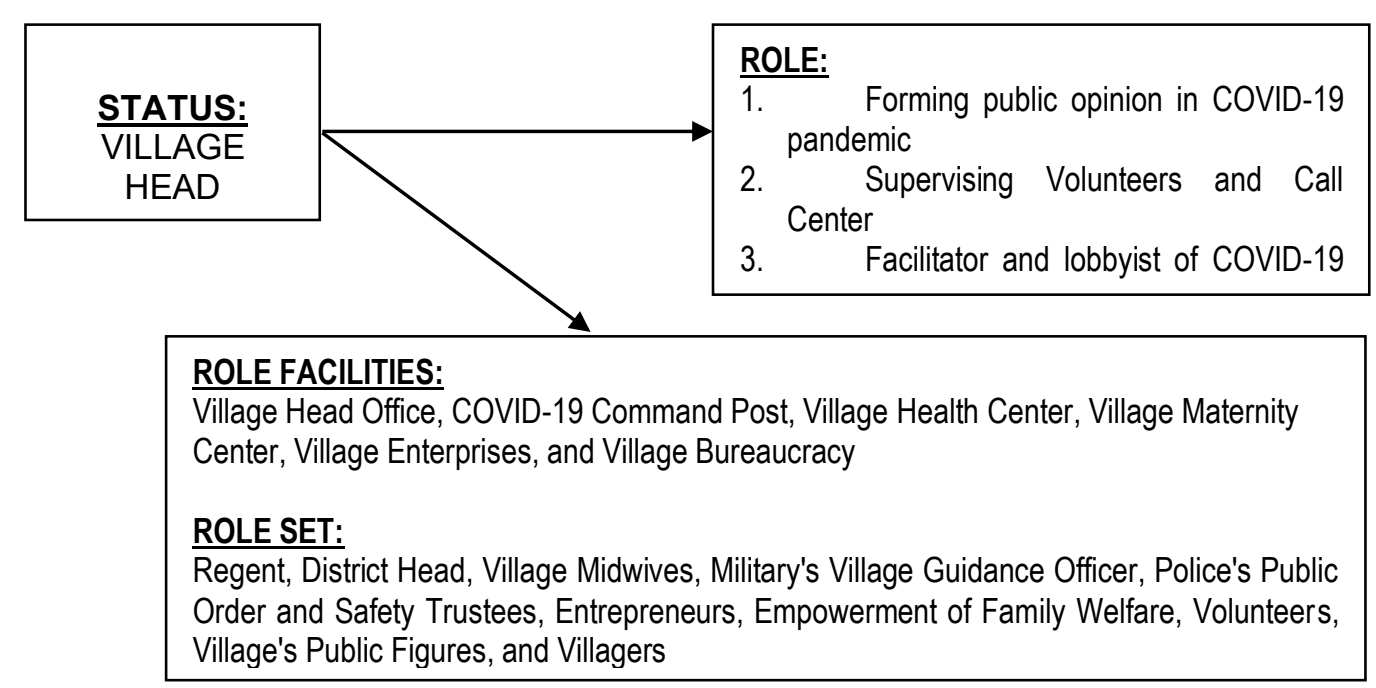

Figure 2. Role and Status of Village Head during COVID-19 Pandemic

Welfare, Village Youth Organization, et cetera, village's COVID-19 volunteers, village's public figure, and villagers as a whole.

This research specifically aims to reveal the concept of patron-client relationship and role theory concepts that can be elaborated deeper related to the analysis of the village head's role during the COVID-19 pandemic in Sampang regency. Furthermore, this research will interrogate the development of the village head's roles in mitigating the COVID-19 pandemic and adaptation to new life habits (New Normal).

\section{Research Methodology}

This research conducts a qualitative approach (Fernando et al., 2019) and takes study cases of ten villages in Sampang regency, East Java province. The location was selected because of its uniqueness since the entire villagers can maintain green zone status (no active COVID-19 cases) as the longest in East Java. Based on the COVID-19 data, the first confirmed case is recorded on 13 May 2020.

This study is a descriptive analysis to provide a more detailed picture of a phenomenon(Marta \& Setyawati, 2018); (Sampurna et al., 2020). This in-depth description of characteristics is in line with the definition of Denzin's qualitative research method (Denzin \& Lincoln, 2008) which emphasizes on the process and meanings that are not researched closely or have not been measured from the side of quantity, amount, intensity or frequency, and emphasizing on the reality's characteristics built socially, close relations between the researchers and researched subjects (Daniar et al., 2020).

The method used in the primary data collection is through interviewing ten village head's informants in Sampang. Due to the pandemic situation, the interview is conducted by phone to minimize physical contact. Later, secondary data is also required in this research, such as news on the COVID-19 situation in Sampang in various mass media, documentation, and literature reviews.

This article's data analysis stages are organizing, compiling, sorting data, categorizing in particular patterns and categories so its meaning can be understood. The dissected stages are as follows: (1) data collection and selection to understand its relevance; (2) categorizing data based on certain categories; and (3) interpreting available data. The bottom line is that the analysis steps are conducted as an interaction process consisted of data reduction and conclusion or verification (Rijali, 2019).

\section{Results and Discussions}

The village head's involvement in pandemic handling in Sampang's villages is a former public opinion on disease's threat and Coronavirus's danger. As an important figure in the middle of villagers, then an opinion delivered by the village head is proven to influence the villagers to obey the health protocols in daily activity (Feder \& Savastano, 2006).

The village head must have excellent communication skills(Chuang, 2013) so all villagers can understand the delivered message on pandemic mitigation. Even so, 
the status as a leader sometimes influences people not only because of the message but also who delivers the message. Therefore, villagers are frequently seeing the deliverer as more important than the message itself (Rondonuwu, 2018).

Role as an opinion maker is quite essential in delivering the government's programs. In conducting its role, village heads are often delivering formally-constructed opinions (Nunes et al., 2018). For example, the village government responded to the Sampang regent's Circulation Letter number 440/655/434.203/2020 about Effort on Prevention of COVID-19 Transmission by launching the distribution of free face mask for the villagers. This distribution program must utilize the village's own small and medium industries. The village government also can optimize Village's Budget or Dana Desa (DD) to tackle the COVID-19 pandemic.

From the explanation given above, the authors assumed that if the government issues a message of COVID-19 handling policy, then this message announced by a figure of village head that has great credibility and influence among the villagers so that this message (or opinion) can be widely accepted by the public(Kurjunaidi, 2019); (Marta, 2018). In this opinion-forming process, the village head can directly speak to the people through public discussion or more private and informal conversation. Besides those ways, the village head can also indirectly pass the information through the mass media (Marta, 2017), socialization banners, announcement posters, and volunteer team. These media, especially mass media, various parties have the potential to contribute as a medium for understanding messages conveyed in a media. (Agustina et al., 2020). Muarif, the village head of Taman, said:

"I also still make some approach to the people. If I pass the message through something like letters, it will not feel appropriate. Just like the behaviors of farmers: it just does not feel right if I do not pass the message indirectly because even when I pass it directly, they are still struggling to understand" (Interview with Muarif, 15 May 2020).

As it explained in the previous paragraph, the village head, as an opinion former, can do direct verbal interaction(Hidayat, 2016). However, the village head can also do the opinion-forming in nonverbal ways such as exemplary actions and provide exemplary health protocol obedience behavior towards the villagers. This example is later distributed to all villagers to enhance the village head's positive and good image. One of the Taman village's head who is informant explains a nonverbal opinion former model.

\begin{abstract}
"I also celebrated marrying my daughter (during the pandemic), so I asked my prospective inlaws to only send five people, so the people gathered here are not more than ten from both parties. We will hold the party once the pandemic ends. The neighbors said that we even feel ashamed if the celebration is held more festive because we simply have nothing. The celebration was like a funeral because we did not play any music. Even we did not use any sound systems." (Interview with Subaidi, 14 May 2020).
\end{abstract}

In Sampang's case, the village head is the primary reference in public opinion on the development of the COVID-19 pandemic. This is the beginning of obedience, reluctance, and respect from villagers to the leader figure. The village head's opinion can be easily accepted because of the patron-client relationship or village head as the "father protector of the villagers" (Scott, 1972).

This strategic position can make a village head as political communicator of government programs and excellent opinion makers (Wahjudi, 2018). He can optimize opinion channels simultaneously to reach expected goals in pandemic situations: information deliverance for the villagers.

Village Minister's Regulation No. 6/2020 (jdih.kemendesa.go.id, 2020) and Circulation Letter of Sampang regent No. 8/2020 about COVID-19 Responsive Villages (Supriyatno, 2020) appoints a village head as the head of the Board of Village Volunteers Against COVID-19. This is an effort of performance optimization in each village region for the prevention and enforcement during the Coronavirus pandemic.

The COVID-19 village volunteers' forming process influenced the overseeing and implementation of pandemic-related programs in each village. The volunteer team is an essential moment in public participation because the recruitment itself is conducted professionally, independently, transparently, and participative for those villagers who are interested in becoming one(West \& Pateman, 2016).

Sampang's regent asks village heads to consolidate with volunteers, village security forces, and the local community to prevent COVID-19 transmission. The regent's statement also asked the village heads to regard the socio-economic impacts so that 
these steps will be working if supported by all villagers(Duta.co, 2020). Baum explains that villagers participation refers to community involvement in the government in various activities such as planning, organizing, community empowerment, and other activities that allow individuals and representative groups to influence the public decision (and so does private sectors) that illustrates their interests (Bahtiar, 2017); (Listyawati et al., 2019).

The village head of Jelgung confirmed the regent's instruction and added that the Sampang regency's COVID-19 Handling Acceleration Task Force Team has socialized and consolidates all village heads under the umbrella of Village Head's Association in each district. Due to the pandemic, it is impossible to gather all village heads in Sampang regency. His complete statement is as follows:

\begin{abstract}
"Until now, the green zone status cannot be separated from the role of community and government. I, especially, appreciate the regent, whose going to all villages in Sampang to consolidate until 2.00 a.m. From all corners of Sampang until its border with Bangkalan, those areas are also under constant regent observation. Programs launched by Sampang regional government showed that those programs really could be felt by us, not just heard. So we know how hard the local government works during this time." (Interview with Abdul Hamid, 13 May 2020).
\end{abstract}

Furthermore, regarding the regent's instruction on the volunteer operational budget, the village head can utilize Village Budget and Village Budget Allocation. The volunteer assists the village head to socialize villagers on the importance of health protocol during this New Normal era. Some volunteer activities distribute face masks, make handwashing facilities in many village's important spots, guard the command post, and disinfect public facilities. The complete village consolidation process through the volunteer team fighting against the COVID-19 outbreak can be seen in Table 1.

Table 1 explains that the village head's role in consolidating with the volunteers uses a technology-based communication medium, the call center that can monitor COVID-19 handling. Therefore, the village government has ordered the volunteers to quickly respond to people's complaints related to the pandemic supported by electronic devices and the internet. For example, most volunteers socialize the call center in the form of a phone number or WhatsApp number (Nickerson, 2007). Later, the village head also equips the volunteers with handheld communication devices of handie talkie (HT). All those communication devices can ease the coordination between the volunteers and its leader (village head) in preventing COVID-19 spread in the village.

During the COVID-19 pandemic, many villagers were categorized as economically vulnerable due to the market's low purchasing power(Nasution et al., 2020). One reason

Table 1

Number of Command Post, Volunteer Team, and Information Center

\begin{tabular}{lccl}
\hline Village & $\begin{array}{c}\text { Command } \\
\text { Post }\end{array}$ & $\begin{array}{c}\text { Volunteer } \\
\text { Team }\end{array}$ & Call Center \\
\hline Jelgung & 12 & $\mathbf{3 0}$ & HT, Hp, WhatsApp Group \\
Noreh & 2 & 10 & Hp, WhatsApp Group \\
Disanah & 9 & 4 & Hp, WhatsApp Group \\
Taman & 4 & 28 & Hp, WhatsApp Group \\
Labang & 4 & 22 & Hp \\
Rapa Laok & 2 & 21 & HT, Hp, WhatsApp Group \\
Mlakah & 2 & 12 & Hp, WhatsApp Group \\
Napo Daya & 1 & 14 & HT, Hp, WhatsApp Group \\
Panggung & 1 & 25 & HT, Hp \\
Bepelle & 1 & 20 & Hp, WhatsApp Group
\end{tabular}


for the implementation of Large Scale Social Limitation in big cities is to expect fewer people outside, leading to a downward trajectory in disease transmission. But on the other side, many people choose to go back to their village due to the financial burden resulted from the social limitation. In Sampang's case, most village heads admit that there are plans on the arrival of their villagers that worked in the city included in the red zone status or Indonesian workers from abroad. In this homecoming condition, the village government is expected to take the role as the facilitator for the social aid programs for the villagers who have lost their income due to the pandemic-induced crisis.

Social aids that targeted villagers generally goes through the village head as the formal power authority. In this activity, the village head usually acts as a facilitator. This role can be conducted because the village head owns several role facilities such as village bureaucracy, village head office, COVID-19 aid distribution command post, and village health facilities. As a formal leader, the village head facilitates aid programs from its upper power structure (Supradesa) or other actors(Suharto, 2012). One of the roles is to complete the data of everyone that has the right to receive aid. For example, the village head possesses the authority to determine who has the right to receive the Direct Cash Aid - Village Budget or Bantuan Langsung Tunai - Dana Desa (BLT - DD). Even though generally, based on the Village Minister's Regulation No. 6/2020, the criteria on who has the right to receive BLT-DD are poor people registered as the receiver of Prospect Family Program and Non-Cash Food Aid, lost a job due to COVID-19 pandemic, and has a certain family member with the vulnerability of being chronically ill.

Hereinafter, the village head's role can also be a facilitator of basic needs distribution from non-government actors (private) (Antlöv et al., 2016). Technically, the village head only provides aid receiver data and distribution or activity of aid distribution. Based on interviews with few village heads, because the basic needs aid still relatively small, it is not uncommon that they usually spare their own money, such as thing done by the village head of Bepelle:

"The operational money (for basic needs aid
distribution) comes from the village head."
(Interview with Zainuddin, 14 May 2020).

This sacrifice happens because the village head is a leader with the highest responsibility towards its people. Therefore, the facilitator role is also included in fulfilling the villager's needs that were impacted by the COVID-19 pandemic and categorized as economically disadvantaged family groups in the village.

As a facilitator, the village head also demanded strong relations with the upper power structure (Supradesa)(Hariri, 2019). They also become an intermediary party of villager welfare programs from either regional or central government. Therefore, the power relation between the regent and village head during the pandemic should be collaborative, mainly on the social aid distribution process. Principally, social aid during the COVID-19 pandemic must be right on target and free from the village government's cut. Moreover, there are many types of aids for the villagers impacted by the COVID-19 pandemic, and it comes from many parties.

"The aids are from the central government, Sampang government, and other parties." (Interview with Abdul Hamid, 13 May 2020).

Therefore, the village government must be transparent in opening the aid receiver's data towards the public to maximize the overseeing of the social aid distribution, and the village head can avoid the suspicion of misappropriation of social aid distribution.

The existence of village head with three forms of strategic role during the pandemic is relevant with the role theory concept by Ralp Linton (Stryker, 2001) and Soekanto (Gayatri \& Widhiyani, 2020) because the village head has role facilities such as village head office, COVID-19 aid command post, village medical center, and village bureaucracy. Besides, the village head also has a role set. In this context, a village head interacts with parties with interest in a political and social community system such as regent, district head, security forces, entrepreneurs, community organizations, village's COVID-19 volunteers, public figures, and villagers as a whole.

Through those role apparatus, the village head has the power relation with the upper bureaucratic system (Supradesa) to conduct lobbies of welfare programs (Purwoko, 2016) for villagers who lost their income due to the COVID-19 pandemic. Besides, this study found that the patron-client relationship of James Scot (Norris, 1984) between the village head and Madurese villagers is still 
quite strong during the pandemic. Hence, the village head takes the position of the village protector.

\section{Conclusions}

The village head has a high and respected status and position and roles as a patron or "father protector" for other villagers (client) related to their role and contribution during the COVID-19 pandemic in 2020. This research discovers three forms of village head's roles: (1) role in forming a public opinion to beware of the COVID-19 disease. As an opinion leader figure, the village head appeals to the villagers to obey health protocols in daily activities and socialize government programs to prevent COVID-19 disease transmission. (2) consolidation role through volunteers and village call center. As an example, the power consolidation process through the formation of the volunteer team of COVID-19 Standby Village, then an information center to monitor the countermeasures of the pandemic and fast response service of public complaints if experiences or knows COVID-19 symptoms. (3) as a facilitator of COVID-19 social aid. The existence of the variety of social aid that targets villagers generally requires an intermediary actor. The village head is a holder of the formal power authority, enabling a village head to be a facilitator of the villager's welfare aid program distribution.

\section{References}

Agustina, A., Dewi, T. T., Soemantri, N. P., Qureshi, N. Y., \& Moenanto, G. (2020). Environmental Communication in Indonesian Television News Coverage. Aspiration Jurnal, 1(1), 56-72.

Antlöv, H., Wetterberg, A., \& Dharmawan, L. (2016). Village Governance, Community Life, and the 2014 Village Law in Indonesia. Bulletin of Indonesian Economic Studies, 52(2), 161-183. https://doi.org/10.1080 /00074918.2015.1129047

Aspinall, E., \& Rohman, N. (2017). Village Head Elections in Java: Money Politics and Brokerage in the Remaking of Indonesia's Rural Elite. Journal of Southeast Asian Studies, 48(1), 31-52. https://doi. org/10.1017/S0022463416000461

Bahtiar, N. A. (2017). Partisipasi Masyarakat dalam Pengawasan Program Alokasi Dana Desa ( Add) di Desa Panjunan Kecamatan Sukodono Kabupaten Sidoarjo. Kebijakan Dan Manajemen Publik, 5(3), 1-14.
Basri, A. (2020). Tanggulangi Covid-19, Bupati Imbau Optimalkan Penggunaan $D D$. Radarmadura.Jawapos.Com. https://radarmadura.jawapos.com/ read/2020/04/09/188019/tanggulangicovid-19-bupati-imbau-optimalkanpenggunaan-dd

Biddle, B. J. (1986). Recent Developments in Role Theory. Annual Review of Sociology, 12(1), 67-92. https://doi.org/10.1146/ annurev.soc.12.1.67

Chen, X., Ran, L., Liu, Q., Hu, Q., Du, X., \& Tan, X. (2020). Hand Hygiene, Mask-wearing Behaviors and its Associated Factors During the COVID-19 Epidemic: A crosssectional Study Among Primary School Students in Wuhan, China. International Journal of Environmental Research and Public Health, 17(8), 1-11. https://doi. org/10.3390/ijerph17082893

Chuang, S.-F. (2013). Essential Skills for Leadership Effectiveness in Diverse Workplace Development. Online Journal for Workforce Education and Development, 6(1), 34-55. https:// opensiuc.lib.siu.edu/cgi/viewcontent. cgi ?article $=1133 \&$ context $=0$ jwed

Coser, L. A., \& Rosenberg, B. (1964). Sociological Theory: A Book of Readings. Social Forces, 43(2), 268-268. https:// doi.org/10.2307/2574347

Daniar, A., Marta, R. F., \& Sampurna, A. (2020). Defining Brand Identity of Noesa Woven Fabrcis Through Total Branding in Online Media. Diakom : Jurnal Media Dan Komunikasi, 3(1), 77-88. https://doi. org/10.17933/diakom.v3i1.105

Denzin, N. K., \& Lincoln, Y. S. (2008). Handbook of Qualitative Research. Journal of Advanced Nursing, 33(6), 847847. https://doi.org/10.1111/j.13652648.2001.0472a.x

Duta.co. (2020). Bupati Intruksikan Kades Gunakan DD-ADD untuk Cegah Corona. Duta.Co. https://duta.co/bupatiintruksikan-kades-gunakan-dd-adduntuk-cegah-corona

Feder, G., \& Savastano, S. (2006). The Role of Opinion Leaders in the Diffusion of New Knowledge: The Case of Integrated Pest Management. World Development, 34(7), 1287-1300. https://doi.org/10.1016/j. worlddev.2005.12.004

Fernando, J., Sya, M., \& Marta, R. F. (2019). Amalgamation as a Strengthening Ethic. MIMBAR : Jurnal Sosial Dan Pembangunan, 35(2), 334-341. https:// doi.org/10.29313/mimbar.v35i2.4863

Gayatri, \& Widhiyani, N. L. S. (2020). 
Peranan BUMDesa dalam Meningkatkan Kemandirian Ekonomi Desa. E-Jurnal Akuntansi, 30(6), 1593. https://doi. org/10.24843/EJA.2020.v30.i06.p19

Hariri, A. (2019). Eksistensi Pemerintahan Desa Ditinjau dari Perspektif Asas Subsidiaritas dalam Undang-Undang Nomor 6 Tahun 2014 Tentang Desa. Legality: Jurnal Ilmiah Hukum, 26(2), 253. https://doi. org/10.22219/jihl.v26i2.7799

Heckman, R., \& Galletta, D. F. (1988). Changing Roles in IS: A Role Theory Perspective. Proceedings of the Ninth International Conference on Information Systems, 265-274.

Hidayat, E. (2016). Peran Kiai pada Pemilihan Presiden 2014 di Pesantren Areng-Areng Pasuruan Jawa Timur. Governance Jurnal Kebijakan \& Manajemen Publik, 6(1)

Hidayat, E., \& Miskan. (2018). Birokrasi dan Politik: Netralitas Perangkat Desa dalam Pemilihan Kepala Desa Sitimerto Kecamatan Pagu Kabupaten Kediri. Jurnal Aplikasi Administrasi, 21(2), 79-97. http://ejurnal.fisipuht.or.id/index.php/ JAA/article/view/106

Hidayaturrahman, M. (2020). Peran Wakil Rakyat dalam Pembangunan di Daerah Pemilihan Sumenep. JURNAL SOSIAL POLITIK, 6(1), 128. https://doi. org/10.22219/sospol.v6i1.5808

jdih.kemendesa.go.id. (2020). Peraturan Menteri Desa, Pembangunan Daerah Tertinggal, dan Transmigrasi Republik Indonesia Nomor 6 Tahun 2020. In peraturan.bpk.go.id. https://peraturan. bpk.go.id/Home/Details/139739/ permendes-pdtt-no-6-tahun-2020

Kurjunaidi. (2019). Peran Kepala Desa sebagai Opinion Leader. ADMINISTRAUS - Jurnal IImu Administrasi Dan Manajemen, 3(1), 1-20. https://ejournal.stiabinabanuabjm. ac.id/index.php/administraus/article/ view/66

Latifah, L., \& Larasati, D. (2018). Demokrasi dan Organisasi Masyarakat Sipil: Malang Corruption Watch. JURNAL SOSIAL POLITIK, 4(1), 168. https://doi. org/10.22219/sospol.v4i1.5567

Lisnawati, L., \& Lestari, S. (2019). Analisis Faktor Pembangunan Desa dalam Pengembangan Desa Mandiri Berkelanjutan pada Desa Bunghu Aceh Besar. Publisia: Jurnal IImu Administrasi Publik, 4(2). https://doi.org/10.26905/ pjiap.v4i2.3390

Listyawati, D., Sarmiati, Dan, \& Asmawi. (2019). Komunikasi Perangkat Nagari dan Partisipasi Masyarakat dalam Pengelolaan
Dana Desa. JISPO VOL. 9 No. 1 Edisi: Januari-Juni Tahun 2019, 9(1), 97-106. https://doi.org/https://doi.org/10.15575/ jispo.v9i1.4143

Marta, R. F. (2017). Refleksi Hibriditas Budaya dalam Pancasila pada Realitas dan Media sebagai Identitas Bangsa. Bricolage: Jurnal Magister IImu Komunikasi, 3(1), 1-12. https://journal.ubm.ac.id/index. php/bricolage/article/view/841/745

Marta, R. F. (2018). Identifikasi Integritas pada Komunikasi Kwee Tjie Hoei dalam Film Love and Faith. Jurnal Komunikasi Ikatan Sarjana Komunikasi Indonesia, 3(2). https://doi.org/10.25008/jkiski. v3i2.229

Marta, R. F., \& Setyawati, N. W. (2018). Perilaku dan Konflik Sosial terhadap Keputusan Pembelian Produk Iklan Baru di Televisi. National Conference of Creative Industry. https://doi.org/10.30813/ncci. v0i0.1303

Mei Ling, L. (2020). Institusi Sosial: Perannya dalam Keberlangsungan Ruang Publik Terpadu Ramah Anak di Jakarta. Jurnal Muara Sains, Teknologi, Kedokteran Dan IImu Kesehatan, 3(2), 193. https://doi. org/10.24912/jmstkik.v3i2.3367

Musta'an. (2019). The Chosen Village Head Leadership in Carrying Out Government Duties: Analysis Study of Sidoharjo Village Head, Susukan, Semarang. International Journal of Seocology. https://doi. org/10.29040/seocology.v1i01.5

Nasution, D. A. D., Erlina, E., \& Muda, I. (2020). Dampak Pandemi COVID-19 terhadap Perekonomian Indonesia. Jurnal Benefita, 5(2), 212. https://doi. org/10.22216/jbe.v5i2.5313

Nickerson, D. W. (2007). Quality Is Job One: Professional and Volunteer Voter Mobilization Calls. American Journal of Political Science, 51(2), 269-282. https://doi.org/10.1111/j.15405907.2007.00250.x

Norris, W. (1984). Patron-Client Relationships in the Urban Social Structure: A Brazilian Case Study. Human Organization, 43(1), 16-26. https://doi.org/10.17730/ humo.43.1.mxjj248nu0181x4m

Nunes, R. H., Ferreira, J. B., Freitas, A. S. de, \& Ramos, F. L. (2018). The Effects of Social Media Opinion Leaders' Recommendations on Followers' Intention to Buy. Review of Business Management, 20(1), 57-73. https://doi.org/10.7819/rbgn.v20i1.3678

Nurhadi, N., \& Sunarso, S. (2018). Peran Kiai dalam Membangun Partisipasi Pemilih. Jurnal IImiah Pendidikan Pancasila Dan 
DWI WAHYU PRASETYONO, et al. Patron-Client Relationship between Village Heads and Their Residents during...

Kewarganegaraan, 3(2), 169. https://doi. org/10.17977/um019v3i2p169-175

Phahlevy, R. R., \& Multazam, M. T. (2018). The Shifting of Village Autonomy Concept in Indonesia. Opcion, 34(85), 2865-2885. https://doi.org/10.31235/osf.io/z8288

Pratt, R., \& Yongvanit, S. (2016). Reflections on Leadership at the Local Level and the Future of Laos. Kasetsart Journal of Social Sciences, 37(2), 67-72. https://doi. org/10.1016/j.kjss.2015.03.001

Purwoko, B. (2016). Bureaucracy and the Politics of Identity: A Study on the Influence of Ethnicity on the Bureaucrat Recruitment Process in Sorong Selatan Regency, West Papua, Indonesia. Journal of Government and Politics, 7(4), 516-550. https://doi. org/10.18196/jgp.2016.0041.516-550

Regent of Sampang. (2019). Peraturan Bupati Sampang Nomor 6 Tahun 2019. http://jdih.sampangkab.go.id/upload/45/ PERBUP_NO_6_TAHUN_2019_TENTANG TATA_CARA_PEMBAGIAN.pdf

Rijali, A. (2019). Analisis Data Kualitatif. Alhadharah: Jurnal Ilmu Dakwah, 17(33), 81. https://doi.org/10.18592/alhadharah. v17i33.2374

Rondonuwu, S. A. (2018). Peranan Opinion Leader dalam Menyampaikan Pesan tentang Pembangunan Desa di Desa Lantung Kecamatan Wori Kabupaten Minahasa Utara. Jurnal Administrasi Publik, 3(45), 1-7. https://ejournal.unsrat.ac.id/ index.php/JAP/article/view/19065/18626

Salim, A., Bulan, W. R., Untung, B., Laksono, I., \& Brock, K. (2017). Indonesia's Village Law : Enabler or Constraint for More Accountable Governance? October, 20. https://opendocs.ids.ac.uk/opendocs/ bitstream/handle/20.500.12413/13324/ Village_law_Indonesia_Final. pdf? sequence $=1$ \&isAllowed $=y$

Sampang Communication and Information Board. (2020). Kabupaten Sampang Sosialisasikan Peraturan Bupati Tentang Pengelolaan Keuangan Desa. Https://Sampangkab.Go.Id/. https:// sampangkabhttps//sampangkab.go.id/ kabupaten-sampang-sosialisasikanperaturan-bupati-tentang-pengelolaankeuangan-desa/.go.id/berita/bupatisampang-beri-arahan-pengelolaan-danadesa-kepada-180-kades/

sampangkab.go.id. (2020). Informasi Penyebaran Covid-19 Kabupaten Sampang. Sampangkab.Go.Id. https:// sampangkab.go.id/rev-covid/

Sampurna, A., Agustina, M., \& Marta, R. F. (2020). Menelisik Pariwara Rinso Warna
Versi Badut dalam Logika Semiologi Barthes. Jurnal Komunikasi Profesional, 4(2). https://doi.org/10.25139/jkp. v4i2.2841

Scott, J. C. (1972). Patron-Client Politics and Political Change in Southeast Asia. American Political Science Review, 66(1), 91-113. https://doi.org/10.2307/1959280

Soekanto, S., \& Sulistyowati, B. (2005). Sosiologi Suatu Pengantar. Rajawali Pers. https://opac.perpusnas.go.id/DetailOpac. aspx?id=1139084

Steenbergen, D. J. (2016). Strategic Customary Village Leadership in the Context of Marine Conservation and Development in Southeast Maluku, Indonesia. Human Ecology, 44(3), 311327. https://doi.org/10.1007/s10745016-9829-6

Stryker, S. (2001). Traditional Symbolic Interactionism, Role Theory, and Structural Symbolic Interactionism: The Road to Identity Theory. In Handbook of Sociological Theory (pp. 211-231). Springer US. https://doi.org/10.1007/0387-36274-6_11

Suharto, D. (2012). Penyelenggaraan Pemerintahan Desa dalam Perspektif Desentralisasi Administratif dan Desentralisasi Politik. Jurnal Bina Praja, 04(03), 153-160. https://doi. org/10.21787/jbp.04.2012.153-160

Supriyatno, H. (2020). Bupati Sampang Terbitkan SE Kewaspadaan Covid-19. Harianbhirawa.Co.Id. https://www. harianbhirawa.co.id/bupati-sampangterbitkan-se-kewaspadaan-covid-19/

Thongpoon, K. (2012). The Role of Village Headmen in Conflict Resolution: A Case Study of Thepha District, Songkhla Province. Sukhothai Thammathirat Open University, 4(1)(July), 58-69. https://www.researchgate.net/ publication/263844872_The_Role_ of_Village_Headmen_in_Conflict_ Resolution_A_Case_Study_of_Thepha_ District_Songkhla_Province

Wahjudi, S. (2018). Relasi dan Peran Aktor dalam Pemanfaatan RPTRA Kelurahan Pejagalan Jakarta Utara. Bricolage: Jurnal Magister IImu Komunikasi, 4(01), 001. https://doi.org/10.30813/bricolage. v4i01.1648

West, S., \& Pateman, R. (2016). Recruiting and Retaining Participants in Citizen Science: What Can Be Learned from the Volunteering Literature? Citizen Science: Theory and Practice, 1(2), 15. https://doi. org/10.5334/cstp. 8 